56 Lezak MD. Neuropsychological assessment: New York: Oxford University Press, 1976

57 Hatazawa J, Yamaguchi T, Ito $M$, Yamaura $H$, Matsuzawa $T$. Association of hypertension with increased atrophy of brain matter in the elderly. $\mathcal{F} \mathrm{Am}$ Geriatr Soc 1984;32: 370-4.

58 Salerno JA, Murphy DGM, Horwitz B, et al. Brain atrophy in older hypertensive men: a volumetric magnetic resonance study. Hypertension 1992;20:340-8.

59 Mentis MJ, Salerno J, Horwitz B, et al. Reduction of functional neuronal connectivity in long-term treated hypertional neuronal connectivity in

60 Leys D, Pruvo JP, Parent M, et al. Could Wallerian degen- eration contribute to "leuko-araiosis" in subjects free of any vascular disorder? $\mathcal{f}$ Neurol Neurosurg Psychiatry 1991;54:46-50.

61 DeCarli C, Brady D, Katz D, Alston SR, Burger P, et al. Neuropathological findings in Alzheimer's disease with severe leukoencephalopathy. Neurology 1994;44(suppl2): A370-A371.

62 Yao H, Sadoshima S, Kuwabara Y, Ichiya Y, Fujishima M. Cerebral blood flow and oxygen metabolism in patients with vascular dementia of the Binswanger type. Stroke with vascular dem

63 Scheinberg P. Dementia due to vascular disease: a multifactorial disorder. Stroke 1988;19:1291-9.

\title{
Baron Constantin von Economo and encephalitis lethargica
}

Although younger neurologists may not have encountered postencephalitic parkinsonism, encephalitis lethargica merits mention in contemporary reviews of Parkinson's disease. The name of von Economo is inseparably and justifiably attached to the disease since his was the major description ${ }^{1}$ of an illness that raged in epidemic form in Europe and North America between 1916 and 1926. Ivy McKenzie provided a scholarly account of the illness in Glasgow. ${ }^{2}$ Longer texts were written by Jelliffe, ${ }^{3}$ and by Wimmer. ${ }^{4}$ At first, others confused encephalitis lethargica with the pandemic of influenza (Spanish grippe). Cruchet had first noted encephalitis lethargica in the winter of 1915-16 in French soldiers in Verdun, ${ }^{5}$ and a few cases were seen in the spring of 1915 in Rumania.

von Economo published 27 papers including a book $^{6}$ on encephalitis lethargica.

\section{Excerpts from a translation of his classic descrip- tion ${ }^{1}$}

"We are dealing with a kind of sleeping sickness, having an unusually prolonged course. The first symptoms are usually acute, with headaches and malaise. Then a state of somnolence appears, often associated with active delirium from which the patient can be awakened easily. $\mathrm{He}$ is able to give appropriate answers, and to comprehend the situation. This delirious somnolence can lead to death, rapidly, or over the course of a few weeks. On the other hand it can persist unchanged for weeks or even months with periods lasting hours or days or even longer, of fluctuation of the depth of unconsciousness extending from simple sleepiness to deepest stupor or coma .... During the first days of the illness, isolated signs of meningeal irritation appear.... The appearance of fever and its intensity do not seem to have any effect upon the course and signs of the disease....

As a rule these general symptoms are joined by paralysis of the cranial nerves as well as in the extremities ... a paralytic ptosis often combined with partial or total paralysis of other branches of the oculomotor nerve .... Paresis of the other cranial nerves and paralysis of the extremities with reflex disturbances can occur also"

[seven case reports and an account of the clinical features are then given] ....

"The spinal fluid ... showed increased pressure at the beginning; it later decreased in spite of persistent somnolence. The total protein was below the normal upper limit; ... In case 1,43 cells $/ \mathrm{mm}^{3}$, in case 2,19 cells $/ \mathrm{mm}^{3} \ldots$ strong predominance of polymorphonuclear leukocytes. Repeated examina- tions for microorganisms was negative in every case. The Wassermann reaction in serum and spinal fluid was always negative ....

As the residual of such a paresis (upper and lower extremities), spasms, increased reflexes, or the Babinski phenomenon can persist for a long time, even after the ocular muscle paralysis and somnolence have receded ... one often finds a peculiar rigidity of the extremities (cases 1,2 and 4). Like most of the signs this rigidity disappears later ... We frequency find (cases $1,2,3,4,7$ ) ataxic disturbances that make one think of involvement of the cerebellum. Case 7 demonstrated severe ataxic tremor .... With reference to pontine encephalitis I describe briefly several cases seen in the emergency room during the same period"

[six further case reports and a long discussion on differential diagnosis and pathology follow] ...

von Economo concludes: "Therefore we have the histological picture of a polioencephalitis cerebri, pontis et medullae oblongatae, with a slight poliomyelitis of a perivascular, inflammatory and diffusely infiltrative but not haemorrhagic and only slightly neuronophagic character."

Born in Braila, Rumania, of an aristocratic Greek family he studied engineering before reading medicine in Vienna. Early training was with Nothnagel, Pierre Marie, and Kraepelin before he returned to the psychiatric clinic in Vienna.

His work centred on neuroanatomy, head injuries in the first world war, and investigations on sleep, cortical architecture, and on Wilson's disease.

$\mathrm{He}$ married the daughter of Prince Alois von Schönburg-Hartenstein, and being of independent means, rejected the chair of psychiatry on von Jauregg's retirement in 1928 . He died suddenly of heart disease in 1931 .

\section{J M S PEARCE 304 Beverley Road, Anlaby, Hull HU10 $7 B G, U K$}

1 von Economo C. Encephalitis lethargica. Wien Klin Wschr 1917;30:581-5 (for full text of translation see Wilkins RH, Brody IA. Encephalitis lethargica. Arch Neurol 1968;18:324-8)

2 McKenzie I. Discussion of epidemic encephalitis. Epidemiological considerations. $B M \mathcal{F} 1927 ; 1: 532-4$.

3 Jelliffe SE. Post-encephalitic respiratory disorders. New York: Nervous and Mental Disease Publishing Company, 1927.

4 Wimmer SA. Chronic epidemic encephalitis. London: Heinemann, 1924

5 Cruchet $R$. The relation of paralysis agitans to the parkinsonian syndrome of epidemic encephalitis. Lancet 1927; i: 264 .

6 von Economo C. Encephalitis lethargica: its sequelae and treatment (KO Newman's translation of Die Encephalitis, Wien 1929). London: Oxford University Press, 1931. 